\title{
A man who had known his star in the sky. A homage to Professor Eugen Grebenikov (1932-2013)
}

\section{VASILE BERINDE}

\section{ABSTRACT.}

The main aim of this note is to present some data about the education, professional activity and scientific publications of Professor Eugen Grebenikov (1932-2013), a distinguished mathematician born in 1932 at Slobozia Mare, Ismail county, Romania (now in Republic of Moldova) who was educated and had worked for most of his life time in Moscow. Some author's personal recollections are also included.

Acknowledgements. I am very grateful to Mrs. Daliana Bonaţ from the County Library "Petre Dulfu" in Baia Mare (Biblioteca Județeană "Petre Dulfu" din Baia Mare), who searched in the archive for the original text of the interview I published in 1994 [?], thus making possible the inclusion of Section 6 of this note.

I also thank Professor Vasile Glăvan for providing an electronic copy of the paper [?] and also for the information he sent to me on the family of Professor Grebenikov.

\section{REFERENCES}

[1] Berinde, V., A man who know his star in the sky. Interview with Professor dr. doc. Eugen Grebenikov (In Romanian), Glasul Maramureşului, Anul VI, Serie Nouă, Nr. 1422, Sâmbătă 16, - Duminică, 17 iulie 1994, pp. 1, 3

[2] Ciobanu, V., Nume şi Lume, Editura Pontos, Chişinău, 2008

[3] Cronţ, B., I've never seen my own star, but I know it is shining [Nu mi-am văzut niciodată steaua, dar ştiu că străluceşte], Ziarul Lumina, 7 octombrie 2011, http:/ / ziarullumina.ro/reportaj/nu-mi-am-vazut-niciodata-steaua-dar-stiu-ca-straluceste

[4] Găină, A., Matematicieni din Basarabia. Eugen Grebenicov, Foaie Matematică, 1997, No. 3, pp. 71

[5] Kerimov, M. K., On the 75th Birthday of Professor Evgenii Aleksandrovich Grebenikov, Comput. Math. Math. Physics, 48 (2008), No. 2, 185-189 [Original Russian, M. K. Kerimov, 2008, published in Zhurnal Vychislitelnoi Matematiki i Matematicheskoi Fiziki, 2008, Vol. 48, No. 2, pp. 195-200]

[6] Kolchinskii, I. G., Korsun, A. A. and Rodrigez, M. G., Astronomi. Ghid biografic. Kiev, Naukova dumka, 1986

[7] Marin, G., Misiuni şi destine, Editura Pontos, Chişinău, 2008

[8] Păsat D., Omul şi asteroidul Grebenicov, Editura Pontos, Chişinău, 2008

[9] Soltan, P. et al., Calendarul Naţional, 2002, pp.38

[10] ***, Dicţionar Enciclopedic de nume proprii, Editura Cartier, Bucureşti-Chişinău, 2004

[11] ***, Enciclopedia Sovietică Moldovenească

Department of Mathematics AND COMPUTER SCIENCE

NORTH UNIVERSITY OF BAIA MARE

Victoriei 76, 430072 Baia MARE ROMANia

E-mail address: vberinde@ubm.ro; vasile_berinde@yahoo.com 